\title{
HIGH DENSITY JUVENILE SHRIMP (Penaeus monodon) PRODUCTION WITH DIFFERENT DURATIONS OF REARING IN ACID SULFATE SOIL-AFFECTED POND
}

\author{
Akhmad Mustafa*\# and Jesmond Sammut ${ }^{* *}$ \\ ") Research Institute for Coastal Aquaculture, Maros 90512 , South Sulawesi \\ **) School of Biological, Earth and Environmental Sciences, The University of New South Wales, \\ Sydney, NSW 2052, Australia
}

(Received 22 January 2010; Accepted 27 April 2010)

\begin{abstract}
An experiment was conducted to evaluate the effectiveness of producing juvenile shrimp in a reservoir pond constructed in acid sulphate soils (ASS). Many ponds constructed in ASS pose a significant economic risk due to high mortality and poor growth. In Indonesia, abandonment of ponds in ASS is widespread and alternative farming practices, such as production of juvenile shrimp, offer farms opportunities to lower their production risks. The experiment involved rearing juvenile shrimp at a high stocking density $\left(3,000\right.$ individuals $\left./ \mathrm{m}^{2}\right)$ using hapas in a formerly unproductive pond located in Luwu Regency, South Sulawesi, Indonesia. The treatments tested included rearing periods of three and six weeks with four replications. A survival of 83.62\% was achieved after rearing for three weeks compared to $45.44 \%$ after six weeks. Although there was a sixfold increase in the mean weight of shrimp from three to six weeks of culture, size variation after six weeks was large due to the high density of shrimp. The experiment showed that old acid sulphate soil-affected ponds, in which the bottom soil has not been excavated any further, can be used for production of juvenile shrimp in hapas. Rearing over three weeks is recommended to obtain high survival and reduce size variation.
\end{abstract}

KEYWORDS: density, duration, juvenile, tiger shrimp, South Sulawesi

\section{INTRODUCTION}

The tiger shrimp (Penaeus monodon) is the dominant species cultured in brackishwater aquaculture ponds in Indonesia. Over the last decade tiger shrimp has contributed significantly to the economic growth of rural communities (Anonim, 2003) largely through the conversion of rice farming areas and, unfortunately, mangroves. The rapid growth of shrimp monoculture, mainly under improved extensive farming systems, has often led to short term success. In 1999, there were 393, 196 ha of ponds in Indonesia (Anonim,
2004), most of them have been abandoned or are considered unproductive principally due to recurrent shrimp disease outbreaks or pond degradation caused by acid sulfate soils (Sammut \& Hanafi, 2000). There are an estimated 6.7 million ha of acid sulfate (ASS) soils in Indonesia and over 35\% are developed for aquaculture (Mustafa, 2007). Acid sulfate soils contain iron pyrite which is harmless to the environment until it is exposed to oxygen, mainly through the use of this soil for the construction of dykes, pond and canals (Sammut, 1999). Oxidation of pyrite will cause

\# Corresponding author. Research Institute for Coastal Aquaculture, Jl. Makmur Dg. Sitakka No. 129, Maros 90512, South Sulawesi, Indonesia. Tel.: + 62411371544

E-mail address: akhmadmustafa@yahoo.com 
severe soil acidification $(\mathrm{pH}<4)$ and elevate concentrations of dissolved aluminum, iron and manganese. Most of the ASS is found in the larger islands of Sumatra, Kalimantan, Sulawesi, and Irian Jaya (Sammut \& Hanafi, 2000). Although soil acidification and disease can, to some extent, be managed to reduce impacts on production, many farmers cannot afford the higher input costs associated with remediating acid sulfate soils or have limited access to disease screening services. Consequently, many ponds remain abandoned.

A sudden and extreme decline in the water quality is often encountered in ASS affected ponds due to the release of acid and toxic metals such as iron and aluminum (Sammut, 1999). These oxidation products can cause gill damage in shrimp and fish and often trigger mass mortalities in stock, particularly after the wet season when ponds are poorly buffered. Mustafa (2007) showed that the pond bottom is a toxic zone for shrimp and suggested that hapas (net enclosures) could be used to rear juvenile shrimp above this zone to minimize exposure to metals, acidity and also hydrogen sulfide gas.

Juvenile shrimp production is a growing industry in Indonesia and has the potential to replace higher risk shrimp grow out systems and to add another component to polyculture (Sammut et al., 2003). The use of earthen ponds as nurseries can produce high quality juvenile shrimp that are sought after by farmers. Juvenile shrimp are preferred over post larvae (PLs) because they are more tolerant of poor water quality also have a greater survival rate because weaker individuals usually die early in the cropping period leaving more robust stock for stocking in nearby, non-ASS grow out ponds. Predation by pests is also less of a problem with juvenile shrimp.

Juvenile shrimp also have a shorter growing period due to faster growth rates (Rodriguez et al., 1993). Pond yields are consequently much more reliable and larger than in systems stocked with PLs. In Indonesia juvenile shrimp production helps to maintain a regular of supply stock enabling farmers to avoid relying on PLs which may be diseased or weak. Farmers may also rear juvenile shrimp in reservoir ponds during the pond preparation stage of adjacent grow out ponds.

Muliani \& Mustafa (1995) and Mustafa et al. (1995) successfully reared juvenile shrimp in peat soils. In aquaria with peat soil substrate, Mustafa (1996) produced good quality shrimp in 30 days. Primavera (1977) carried out nursery rearing of shrimp in hapa which were then placed in a pond for 40-52 days. Somalingam \& Murthy (1979), Siddharaju et al. (1980), Martosudarmo (1983), Rodriguez et al. (1993), and Yusufzai \& Singh (2005) each trialed the hapa system for 30 days. However, no previous studies specifically investigate the use of hapa for juvenile shrimp production in ASS. Clearly, the use of hapas for rearing has potential for use in ASS-affected ponds.

Past studies on the stocking of juvenile shrimp in grow out ponds in Indonesia reported shorter culture periods, higher survival rates and weight, and lower feed conversion ratios compared to directly seeding ponds with PLs (Mangampa et al., 1990; Mustafa \& Mangampa, 1990; Mangampa \& Mustafa, 1992; Mangampa et al., 1994). These studies also showed that rearing of shrimp over 60 rather than 30 days improved production further. However, these trials were conducted in peaty soils rather than the more toxic environment of ASS.

The present study trialed juvenile shrimp production using hapas comparing production over three and six weeks to identify which of the two periods is best suited for ASS-affected ponds. The use of hapa for juvenile shrimp production has the potential to attract farmers back to abandoned ponds that would otherwise be too expensive or risky to restore for monoculture grow out.

\section{MATERIALS AND METHODS}

The experiment was conducted in a farmer's ASS-affected pond in Pinrang SubDistrict, Luwu Regency, South Sulawesi Province, Indonesia (Figure 1). The experiment lasted for four months, during which pond soils were remediated, walls and dykes were repaired, and the hapas were installed. The remediation technique consisted of bottom soil drying for 2 weeks and flooding with brackishwater three times each day for three days. The remediation process was repeated twice.

The pond was $3,600 \mathrm{~m}^{2}(90 \times 40 \mathrm{~m})$ and was used as the reservoir for grow-out ponds on the farm. The surrounding canal was deepened and widened. The soil excavated from the canal was used to increase the height of the pond dykes thereby avoiding further 


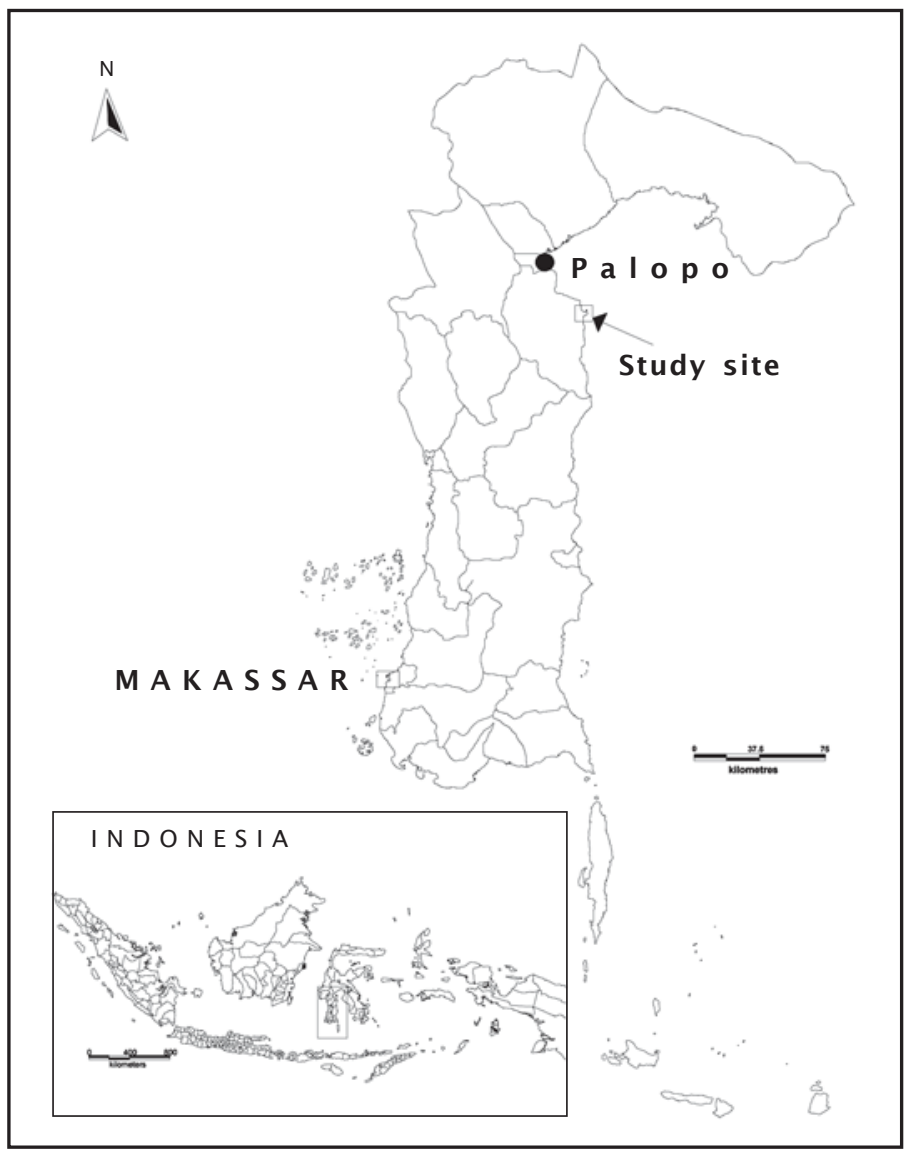

Figure 1. Location of study site in Luwu Regency South Sulawesi Province, Indonesia. Cartography: Tarunamulia

disturbance to the ASS below the remediation zone in the pond bottom. The canal material was limed to treat acid that was quickly produced on exposure to air. A water gate measuring $2.5 \mathrm{~m}$ long, $0.8 \mathrm{~m}$ wide and $2.5 \mathrm{~m}$ high was fixed into position, and a water screen was attached. The pond had a 6 inch diameter water pump to fill the pond at low tide.

Eight hapas were used; four units were used to rear the shrimp for three weeks, and the other four units were used to rear the shrimp for six weeks. The hapas measured 2.0 $\mathrm{m}$ long, $1.0 \mathrm{~m}$ wide and $1.0 \mathrm{~m}$ high. The mesh size of the hapas was $0.3 \mathrm{~mm}$. The hapas were secured with wooden stake attached to the corner of each enclosure. The hapas were arranged in two rows $0.50 \mathrm{~m}$ apart. A wooden catwalk was installed to enable monitoring and maintenance of the hapas. The distance between each hapa in each row was $0.50 \mathrm{~m}$. The bottoms of the hapas were located $0.10 \mathrm{~m}$ above the soil.

A saponin dose of $20 \mathrm{mg} / \mathrm{L}$ was used to eradicate pests and $25 \mathrm{~kg} / \mathrm{ha}$ of urea and 75 $\mathrm{kg} / \mathrm{ha}$ of Triple Superphosphate (TSP) were applied to compensate for reductions in phosphate caused by iron and aluminum. Without fertilizer, it would be difficult to initiate phytoplankton blooms in ASS. The urea and TSP fertilizer was spread evenly on the bottom of the pond. The pond was filled with water by gravitation and with the help of the water pump until the water height in the surrounding canal and the pond reached $0.60 \mathrm{~m}$ or the hapas were flooded to a depth of $0.50 \mathrm{~m}$. Seaweed (Gracilaria verrucosa) weighing $360 \mathrm{~kg}$ fresh and 360 juvenile milkfish (Chanos chanos) were stocked in the pond. 
The shrimp fry (PL-16) were obtained from one of the shrimp hatcheries located in Barru Regency, South Sulawesi. The PLs were tested beforehand for White Spot Syndrome Virus (WSSV) by a Polymerase Chain Reaction (PCR) test (Durand \& Lightner, 2002; Yoganandhan et al., 2003). The shrimp PLs were transported from the hatchery for five hours using a closed system at a density of 1,000 individuals/L. A screening test in a 30 minute formalin bath (200 mg/L) was used before stocking. The shrimp PLs were then adapted to the salinity and temperature of the pond water. The stocking density was 3,000 individuals $/ \mathrm{m}^{2}$. In this experiment no shelter was used in the hapas.

The test treatments consisted of shrimp PLs over three and six week rearing periods. Each treatment had four replications. The experiment was randomized based on Ten Thousand Random Digits (Rohlf and Sokal, 1981).

The shrimp PLs were fed with commercial feed comprising $40 \%$ crude protein, $6 \%$ fat and $6 \%$ fibre in crumble form. The feed dosages were $100 ; 75 ; 50 ; 40 ; 30$ and $20 \%$ of biomass per day in the first, second, third, fourth, fifth, and sixth week after stocking, respectively. The feed was given twice a day, that is, a $40 \%$ of the feed total in the morning and $60 \%$ in the afternoon. An electric weighing scale accurate to $0.01 \mathrm{~g}$ was used to weigh the shrimp. A sample of 100 individuals was weighed weekly from each hapa. Approximately $20 \%$ of the water volume was exchanged daily. Fouling was removed with a soft brush at least once a week. Dead shrimp were removed from the hapa during each monitoring period to avoid fouling and reduce the risk of disease outbreaks.

Water quality measurements included water depth, transparency, temperature, alkalinity, and $\mathrm{pH}$, measured every day in the morning (7:00-8:00). The water depth was measured with a graduated stick, transparency with a Secchi disc, salinity with a refractometer, temperature with a thermometer, alkalinity by titration, and $\mathrm{pH}$ with a $\mathrm{pH}$-meter (lonode IJ44). The water $\mathrm{pH}$ and dissolved oxygen concentration were measured using a Hydrolab ${ }^{\circledR}$ Datasonde for 24 hours at 2 hourly intervals in the third week of nursery rearing of shrimp PLs. Water samples were collected every 2 weeks for wet chemical analyses. The chemical properties of water were analyzed at the Water Laboratory of the Research Institute for Coastal Aquaculture in Maros Regency, South Sulawesi. Water variables that were analyzed included $\mathrm{PO}_{4}$ by ascorbic acid method, $\mathrm{NO}_{3}$ by cadmium reduction method (APHA, 2005), $\mathrm{NO}_{2}$ by colorimetric method, $\mathrm{Fe}$ by phenanthroline method and $\mathrm{SO}_{4}$ by turbidimetric method (APHA, 2005). Soil samples were taken at the time of stocking the shrimp PLs, and then every three weeks after stocking shrimp PLs. Pond bottom soil samples were collected at five points at a depth of 0 to 0.20 $\mathrm{m}$ and were then composited. The soil samples from the dyke soil were taken from the top section of four sides of the pond at a depth of $0-0.20 \mathrm{~m}$ and then composited. The soil samples were collected using a soil auger. Field-based soil measurements included field $\mathrm{pH}\left(\mathrm{pH}_{\mathrm{F}}\right)$ (Ahern \& Rayment, 1998) using an intermediate junction electrode (lonode IJ 44), field $\mathrm{pH}$ after oxidation with $30 \%$ hydrogen peroxide $\left(\mathrm{pH}_{\mathrm{FOX}}\right)$ (Ahern \& Rayment, 1998), and redox (reduction oxidation) potential with an lonode IJ 64 probe. Soil samples were placed in plastic bags, labeled and then kept in an icebox until returned to the laboratory. These samples were then oven dried at a temperature of $80-85^{\circ} \mathrm{C}$ for a minimum of 48 hours (Ahern \& Blunden, 1998) to stop bacterially-mediated oxidation of pyrite. The dry soil was pulverized and then passed though a size 30 mesh screen. The soil quality variables that were analyzed at included: $\mathrm{pH}_{\mathrm{KCl}}(\mathrm{pH}$ of filtered 1:201M KCl extract), $S_{\text {POS }}$ (peroxide oxidisable, $S_{\mathrm{P}}-S_{K C I}$ ) (Ahern et al., 1998b; Ahern \& McElnea, 2004), TPA (total potential acidity in $1 \mathrm{M} \mathrm{KCl}$ peroxide digest titrated to $\mathrm{pH} 5.5$ ), pyrite (Ahern \& Rayment, 1998; Ahern et al., 1998a, 1998b), $\mathrm{PO}_{4}, \mathrm{Al}$, and $\mathrm{Fe}$ (Menon, 1973).

Shrimp were harvested at 3 and 6 weeks. Survival was determined by the number of shrimp stocked divided by number of shrimp harvested $x$ 100: Feed conversion ratios for supplementary feed (in the presence of natural food), was estimated by the formula:

$$
F C R=\frac{f}{b}
$$

where:

$f=$ Weight of feed added

$b=$ Biomass gain of shrimp Parker (1987).

Weight, survival and feed conversion ratio data were presented as mean \pm SE (standard error). The data were then tested with T-Test for two independent samples at the signifi- 
cance level of $95 \%$. Before the T-Test for two samples independence was determined, the data were first of all tested with the F-Test (Levene's Test) to determine the degree of homogeneity of variance. SPSS version 15 was used for all statistical analyses (SPSS, 2006; Coakes et al., 2008).

\section{RESULTS AND DISCUSSION}

\section{Soil and Water Quality}

The soil quality variables from the ASSaffected pond used to rear shrimp fry are shown in Table 1. The $\mathrm{pH}_{\mathrm{F}}$ value in general was near 7 which showed that the soil pH was neutral. It has already been stated that the bottom of the pond used in this research was not deepened (except for deepening of the surrounding canal) with a result that the pyrite in the deeper soil did not oxidise and thus did not cause a decrease in the soil $\mathrm{pH}$. However, the $\mathrm{pH}_{\mathrm{FOx}}$ value can be classed as low which shows that the pond soil had high acidic potential. This can be seen in the value of $\mathrm{pH}_{\mathrm{F}}-\mathrm{pH}_{\mathrm{Fox}}$ which is fairly large, that is between 5.34 units and 5.71 units.

The redox potential of the soil during the research had a negative value, because the soil was in an immersed condition. The redox potential value decreased as length of rearing period increased. A kinetic study shows that the redox potential of soils decreases quickly after inundation, reaches a minimum after several days, increases quickly to a maximum point but is lower than the time of initial inundation and then decreases in an asymptote with time (Ponnamperuma, 1972). According to Boyd (1995), the decrease of the redox potential in soil which is flooded is normal, and the accumulation of organic matter helps to decrease the redox potential of soil.

The variables of soil quality which can affect soil $\mathrm{pH}$, such as $\mathrm{S}_{\mathrm{POS}}$, TPA, pyrite, iron, and aluminium can be seen to decrease with an increase of rearing time. This is possibly caused by dissolution in the water and then being removed from the system when the water is changed. The decrease in the above soil quality variables also raises the soil $\mathrm{pH}$ value as mentioned before. The rise in the $\mathrm{PO}_{4}$ concentration is assumed to be the results of applying the TSP fertiliser with its dosage of $75 \mathrm{~kg} /$ ha given every two weeks.

The variables of water quality, which were measured directly in the field and covered depth, transparency, temperature and salinity, are presented in Figure 2; alkalinity and $\mathrm{pH}$ are presented in Figure 3. The pond water depth during nursery rearing shrimp fry was maintained at about $0.60 \mathrm{~m}$, so as to keep the water depth in hapas at about $0.50 \mathrm{~m}$. The relatively stable water depth impacted also on the relatively stable water temperature with an average of $30.4^{\circ} \mathrm{C}$ during juvenile shrimp

Table 1. Soil quality at different times in an acid sulfate soil-affected pond for nursery of shrimp (Penaeus monodon) fry in Luwu Regency South Sulawesi Province

\begin{tabular}{lccc}
\hline \multirow{2}{*}{ Variables } & \multicolumn{3}{c}{ Week } \\
\cline { 2 - 4 } & $\mathbf{0}$ & $\mathbf{3}$ & $\mathbf{6}$ \\
\hline $\mathrm{pH}_{\mathrm{F}}$ & 6.75 & 6.96 & 7.09 \\
$\mathrm{pH}_{\mathrm{FOX}}$ & 1.19 & 1.25 & 1.75 \\
$\mathrm{pH}_{\mathrm{F}}-\mathrm{pH}_{\mathrm{FOx}}$ & 5.56 & 5.71 & 5.34 \\
$\mathrm{Redox} \mathrm{potential}(\mathrm{mV})_{\mathrm{pH}_{\mathrm{KCl}}}$ & -16 & -79 & -137 \\
$\mathrm{~S}_{\mathrm{POS}}(\%)$ & 5.68 & 5.83 & 5.93 \\
$\mathrm{TPA}(\mathrm{mole} \mathrm{H} /$ tonne $)$ & 2.1210 & 1.9353 & 1.3853 \\
$\mathrm{Pyrite}(\%)$ & 476 & 434 & 424 \\
$\mathrm{Fe}(\mathrm{mg} / \mathrm{L})$ & 2.0960 & 1.9953 & 1.8906 \\
$\mathrm{Al}(\mathrm{mg} / \mathrm{L})$ & 13,032 & 10,244 & 10,140 \\
$\mathrm{PO}_{4}(\mathrm{mg} / \mathrm{L})$ & 926 & 760 & 638 \\
\hline
\end{tabular}




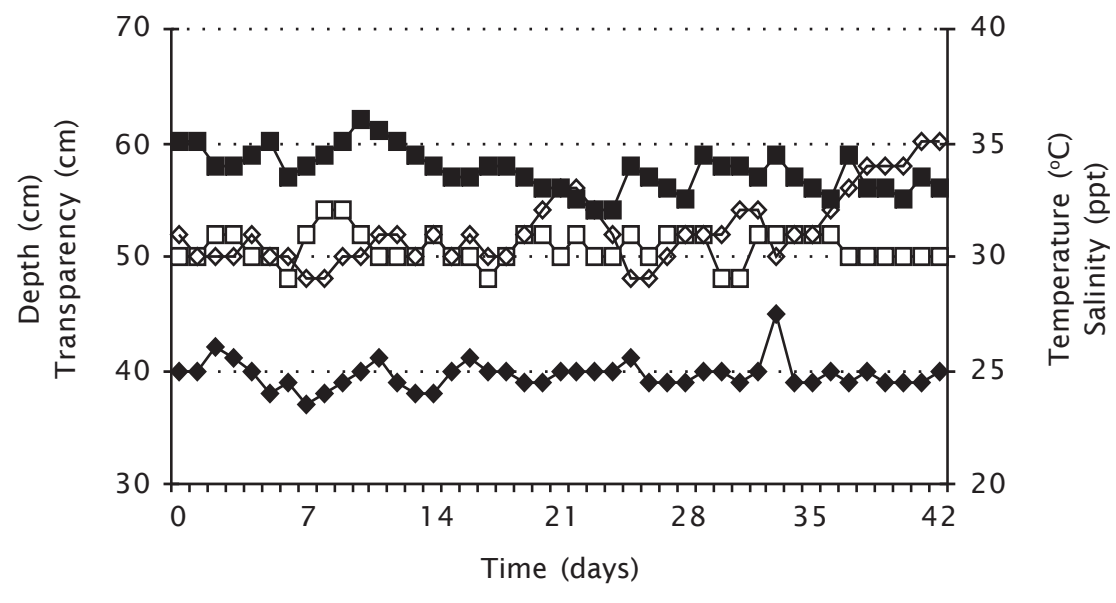

$\neg$ Depth $\multimap$ Transparency $\square-$ Temperature $\multimap$ Salinity

Figure 2. Depth, transparency, temperature, and salinity of water during the nursery of shrimp (Penaeus monodon) fry in an acid sulfate soilaffected pond in Luwu Regency South Sulawesi Province

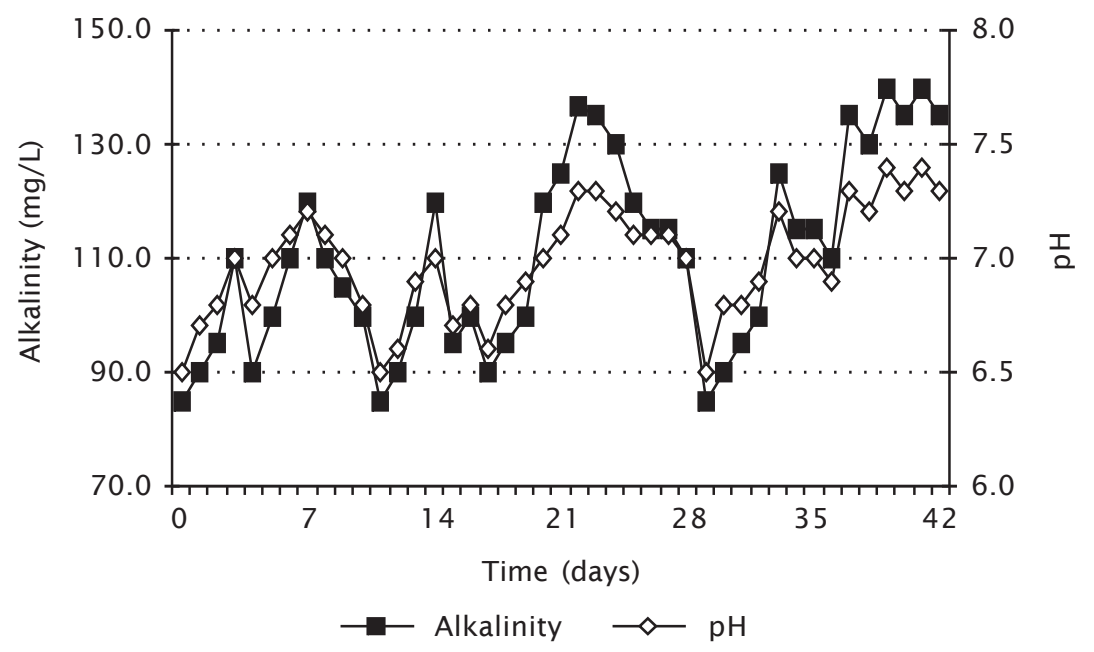

Figure 3. Alkalinity and $\mathrm{pH}$ of the water media during nursery of the tiger shrimp (Penaeus monodon) fry in an acid sulfate soil-affected pond in Luwu Regency South Sulawesi Province

production. Muliani \& Mustafa (1995) have reported that optimum water temperature in peat soil-affected ponds used to rear shrimp fry is $28.5-32.9^{\circ} \mathrm{C}$ with water depth of $0.60 \mathrm{~m}$. According to Boyd (1995) water temperature in the ponds should not change much in a 24 hour period so as not to have a damaging effect on fish and shrimp. The suitable water temperature for shrimp culture is $26-32^{\circ} \mathrm{C}$ and optimally $29-30^{\circ} \mathrm{C}$ (Poernomo, 1988).
Water transparency during nursery rearing of shrimp fry was also stable, that is around 0.37-0.45 $\mathrm{m}$ with a mean of $0.40 \mathrm{~m}$. The water exchange of $20 \%$ every $2-3$ days and continuing fertilisation was able to control the plankton density with the result that water transparency was able to be maintained at about $0.40 \mathrm{~m}$. The optimum water transparency for shrimp is 0.30 $0.40 \mathrm{~m}$ (Poernomo, 1988). Seaweed in the pond also was assumed to play a role in controlling 
water transparency, because seaweed has a capacity to absorb soil colloid particles. Gosavi et al. (2004) also showed that macroalgae will remove toxic metals from the water column.

As with the other water quality variables, salinity was relatively stable, that is about 29 $35 \mathrm{ppt}$ with a mean of $31 \mathrm{ppt}$. The research location did not have a fresh water source, but because the research occurred during the rainy season, this caused the water salinity in the pond to often be less than 32 ppt, which is the general salinity for sea water. Although salinity during nursery rearing periods was not optimum for shrimp, it was able to support the growth and survival of shrimp. Shrimp are able to adapt themselves to salinities of 3-45 ppt, but optimum growth of shrimp occurs at salinities of 15-25 ppt (Poernomo, 1988).

Alkalinity of pond water during nursery rearing of shrimp fluctuated somewhat, with a range of between 85 and $140 \mathrm{mg} / \mathrm{L}$, the mean being $110 \mathrm{mg} / \mathrm{L}$. The pattern of alkalinity fluctuation was similar to the pattern of $\mathrm{pH}$ fluctuation, that is, with high alkalinity levels there were high $\mathrm{pH}$ levels, and the opposite being the case also (Figure 3). The good condition of soil quality, such as $\mathrm{pH}_{\mathrm{F}}$ having 7.0 , as mentioned before, also caused good water $\mathrm{pH}$, that is between 6.5 and 7.4 with a mean of 7.0.

Dissolved oxygen concentration is the most important water quality variable for aquatic organisms (Boyd, 1995). The fluctuation of dissolved oxygen concentration in the pond and in the hapas can be seen in Figure 4. In general, the concentration of dissolved oxygen inside hapas is lower than outside hapas. The calmer condition of the water and the high stocking density of shrimp inside hapas cause a lower concentration of dissolved oxygen inside hapas than outside hapas. The lowest concentration of dissolved oxygen occurred at 06:00 hour and the highest at 12:00 hour both inside and outside hapas. According to Boyd (1995), the maximum concentration for dissolved oxygen occurs in the afternoon and the minimum at or a little after sunset. From Figure 4 it can be seen that the maximum did not occur in the afternoon, and this was because there was rainfall at that time. Also, the lack of sunshine at the time of rainfall impacted on the low concentration of oxygen which is produced during the photosynthesis process. However, the dissolved oxygen found in the hapas still supported the growth and survival of shrimp, although the concentration of dissolved oxygen at 4:00 hour up till 8:00 hour range between 2.07 and $2.83 \mathrm{mg} / \mathrm{L}$ inside the hapas. The appropriate limits of dissolved oxygen for shrimp culture are 3-10 mg/L with 4-7 mg/L as the optimum (Poernomo, 1988). Many researchers have stated that the minimum level of dissolved oxygen needed for shrimp to grow well is $2 \mathrm{mg} / \mathrm{L}$ (ASEAN, 1978).

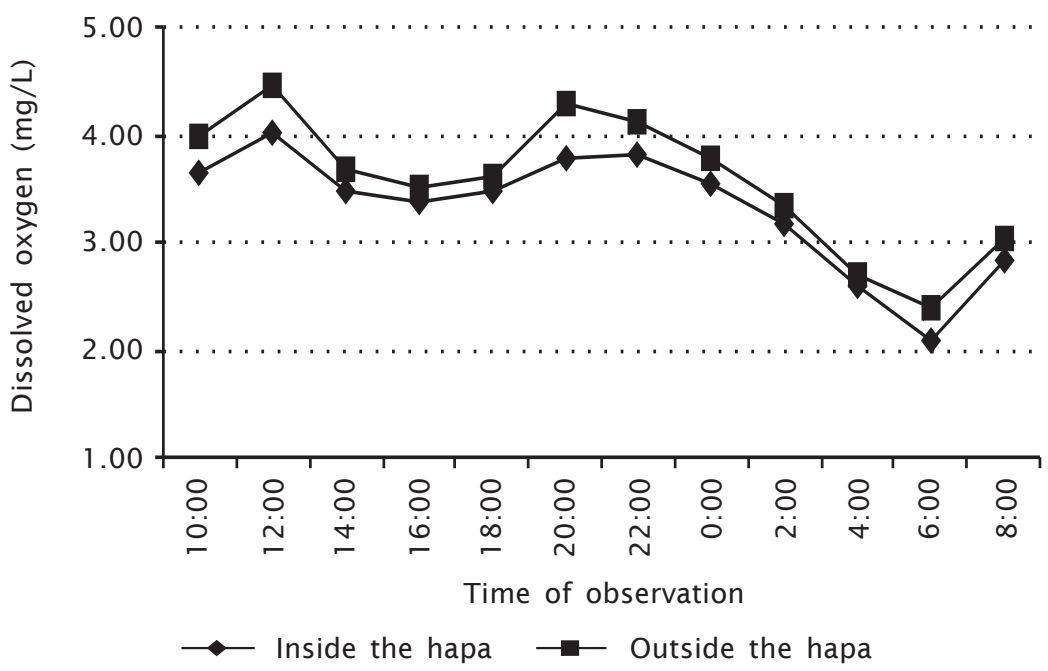

Figure 4. Fluctuation of dissolved oxygen for 24 hours period in the third week of nursery of shrimp (Penaeus monodon) fry in an acid sulfate soil-affected pond in Luwu Regency South Sulawesi Province 
The water quality variables analysed in the laboratory are shown in Table 2. The $\mathrm{PO}_{4}$ concentration was seen as adequate at the beginning and the end of the experiment and was classed as good based on the criteria of Liaw (1969). The $\mathrm{NO}_{3}$ concentration tended to decrease during the experiment. This was assumed to be because the $\mathrm{NO}_{3}$ had been used by plankton. Smayda (1983) has stated that generally plankton prefer to take nitrogen in stages, that is $\mathrm{NO}_{3}, \mathrm{NO}_{2}$, and $\mathrm{NH}_{3}$. So, in this connection, the $\mathrm{NO}_{3}$ was the first to be used by plankton for development with a result that the concentration of $\mathrm{NO}_{3}$ decreased.

Two other forms of nitrogen which were analysed are $\mathrm{NO}_{2}$ and $\mathrm{NH}_{4}$ which are toxic for shrimp. Those two compounds rose in concentration at the end of the experiment but did not reach the concentration that is fatal or that hinders shrimp growth. The $\mathrm{NO}_{2}$ concentration suggested for shrimp culture is less than 0.25 mg/L (Liu, 1989; Chiang et al., 1989; Poernomo, 1989). The iron concentration in the water decreased at the end of the experiment, it was lower than iron concentration $(1.0 \mathrm{mg} / \mathrm{L})$ which is recommended by ANZECC (2000) for shrimp culture. The $\mathrm{SO}_{4}$ concentration decreased at the end of the experiment, and it was assumed that the $\mathrm{SO}_{4}$ was utilised by the heterotrophic bacteria, as stated by Ahmad (1991) or was disposed of when the water was exchanged.

\section{Juvenile Shrimp Production}

The growth in weight of shrimp during the six-week period in the ASS-affected pond can be seen in Figure 5 . The shrimp fry were able to reach a weight of $0.0750 \mathrm{~g}$ after being reared for three weeks and $0.4636 \mathrm{~g}$ after six weeks.
When this is compared to the growth in weight of shrimp reported by past researchers, it shows that the weight obtained in this experiment is less. Although it was reported before that the environmental conditions in which shrimp fry were reared were regarded as appropriate, however, because the density applied was considered high, this caused low growth in terms of weight. Additionally, the survival of shrimp was still high, that is $83.62 \%$, until the third week. This also influenced the slowness in weight growth of shrimp. With a stocking density of 288 individuals $/ \mathrm{m}^{3}$ in hapa for 30 days, Rodriguez et al. (1993) obtained a final weight in shrimp of $0.7800 \mathrm{~g}$. Yusufzai \& Singh (2005) found a final weight of $0.8493 \mathrm{~g}$ after 30 days rearing.

From Figure 5, it can also be seen that the variation in weight for shrimp in different hapas was increasingly greater after the three-week rearing period. The results of these observations also showed the great variation in weight of shrimp in the same hapa after the three-week rearing period. This can be explained by competition for space and food in accordance with the weight increase of shrimp as a result of high density of stocking. The great variation in weight of shrimp which would be stocked in a grow-out pond was not profitable because that weight variation would be increasingly greater when shrimp were being grown in the pond. The weight variation of aquatic organisms can be influenced by some environmental factors such as: stocking density and rearing period or age (Kirpichnikov, 1981). Weight variation of shrimp in low density (less than 10,000 individuals/ha) is lower than in high density (more than 10,000 individuals/ha) (Cholik \& Mustafa, 1987). They also reported

Table 2. Water quality at different times in an acid sulfate soil-affected pond for nursery of shrimp (Penaeus monodon) fry in Luwu Regency South Sulawesi Province

\begin{tabular}{lccc}
\hline \multirow{2}{*}{ Variables } & \multicolumn{3}{c}{ Week } \\
\cline { 2 - 4 } & $\mathbf{0}$ & $\mathbf{3}$ & $\mathbf{6}$ \\
\hline $\mathrm{PO}_{4}(\mathrm{mg} / \mathrm{L})$ & 0.0496 & 0.0695 & 0.0339 \\
$\mathrm{NO}_{3}(\mathrm{mg} / \mathrm{L})$ & 0.3894 & 0.2387 & 0.1899 \\
$\mathrm{NO}_{2}(\mathrm{mg} / \mathrm{L})$ & 0.0031 & 0.0039 & 0.0046 \\
$\mathrm{NH}_{4}(\mathrm{mg} / \mathrm{L})$ & 0.1196 & 0.1332 & 0.1352 \\
$\mathrm{Fe}(\mathrm{mg} / \mathrm{L})$ & 0.2471 & 0.0828 & 0.0774 \\
$\mathrm{SO}_{4}(\mathrm{mg} / \mathrm{L})$ & 62.125 & 53.989 & 32.978 \\
\hline
\end{tabular}




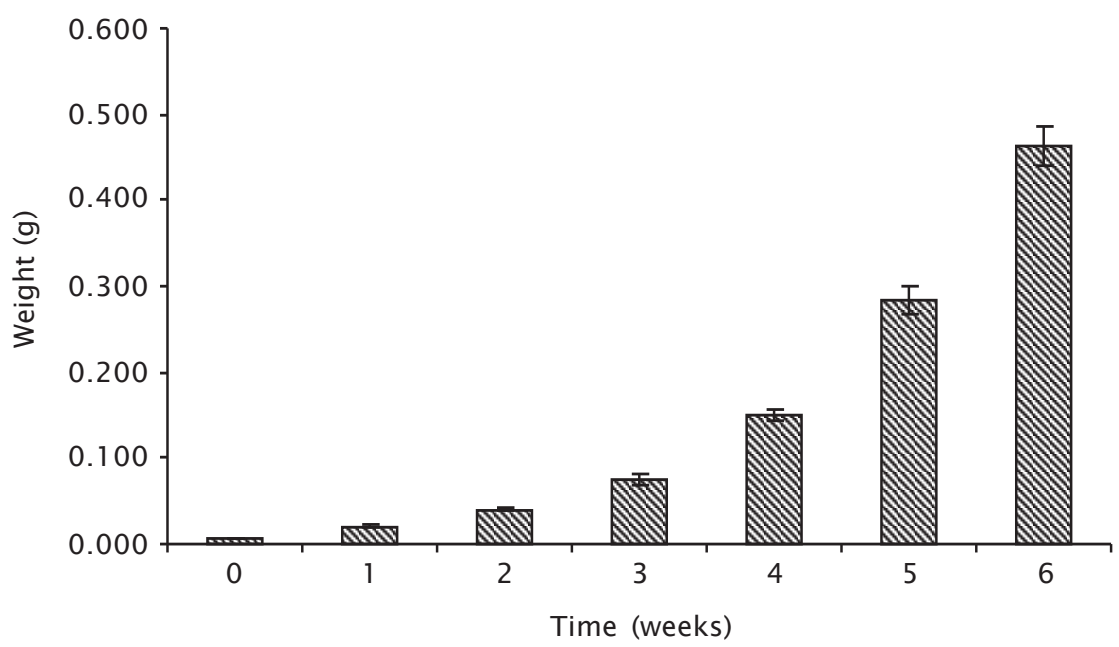

Figure 5. Growth of weight of shrimp (Penaeus monodon) (mean $\pm \mathrm{SE}$ ) reared for six weeks in the acid sulfate soil-affected pond in Luwu Regency South Sulawesi Province

that the weight variation of shrimp cultured for less than 3.5 months is lower than shrimp cultured for more than 3.5 months.

The result of the T-Test on the shrimp fry reared over different time periods showed a significant effect for weight $(P=0.001)$ and survival $(P=0.001)$, whereas different rearing periods did not give significant effect $(P=0.471)$ for FCR (Table 7.3). Greater weight for juvenile shrimp was obtained in the shrimp fry that were reared for six weeks, but on the contrary the high survival was found for the shrimp fry which were reared for three weeks. The FCR for shrimp fry reared for three weeks and six weeks resulted in very similar values, that are 3.28 and 3.54 , respectively.

The survival of shrimp reared up to three weeks was still fairly high, that is $83.62 \%$. Almost the same as the results of this experiment was the result reported for the survival of shrimp (81.30\%) after being reared for 30 days with a stocking density of 200 individuals $/ \mathrm{m}^{2}$ (Siddharaju et al., 1980). However, when reared up to six weeks there was a distinct decrease in survival (45.44\%). With a rearing period that was the same as this experiment, that is $40-52$ days, but with lower stocking density of 200 individuals $/ \mathrm{m}^{2}$, Primavera (1977) obtained a survival of $72.3 \%$. The low survival of shrimp reared over six weeks in this experiment was caused by the high stocking density which gave an opportunity for the possibility of death by cannibalism. The increase in weight of shrimp along with the increased rearing period required a bigger space and sufficient food. Especially so in this experiment which did not use shelter which could enlarge the surface area of the rearing place and also function as a refuge for shrimp to decrease the possibility

Table 3. Weight, survival, and feed conversion ratio of shrimp (Penaeus monodon) reared for three and six weeks in an acid sulfate soil-affected pond in Luwu Regency South Sulawesi Province

\begin{tabular}{lccc}
\hline \multirow{2}{*}{\multicolumn{1}{c}{ Variables }} & \multicolumn{2}{c}{ Week } & \multirow{2}{*}{ Probability } \\
\cline { 2 - 3 } & $\mathbf{0}$ & $\mathbf{3}$ & \\
\hline Weight (g) & $0.0750 \pm 0.0049$ & $0.4636 \pm 0.0230$ & 0.001 \\
Survival (\%) & $83.62 \pm 3.82$ & $45.44 \pm 5.73$ & 0.001 \\
Feed conversion ratio & $3.28 \pm 0.11$ & $3.54 \pm 0.30$ & 0.471 \\
\hline
\end{tabular}


of being eaten by other shrimp. This was in accordance with the results of observations after four weeks of rearing shrimp; many shrimp were encountered with part of the body missing as a result of being preyed upon by other shrimp.

The FCR obtained in this experiment is considered high compared to the experiment previously done. The feed which was given in this experiment was not fully consumed by the shrimp or the feed which was consumed was not accompanied by a significant increase in shrimp weight. The giving of feed only twice a day was assumed to cause the high FCR obtained in this experiment. Although the water stability of feed is good, the shrimp prefer the feed that has not been in the water for a long time (Akiyama \& Chwang, 1989). Nursery rearing of shrimp with the hapa system in peat soilsaffected ponds for 20 days with a stocking density of 750 individuals $/ \mathrm{m}^{2}$ gave a FCR of 2.4 (Mustafa \& Mansur, 1994). In aquaria with peat soil substrate, Mustafa (1996) obtained a FCR of juvenile shrimp of 1.5 , with stocking density of 500 individuals $/ \mathrm{m}^{2}$ for 30 days.

\section{CONCLUSIONS}

Old acid sulphate soil-affected ponds, of which the bottom soil has not been reexcavated, can be used for production of juvenile shrimp using the hapa system. With a high density of shrimp PLs (3,000 individuals/ $\mathrm{m}^{-2}$ ), a survival rate of $83.62 \%$ can be obtained after rearing for three weeks. Feed adjustments are required to improve the method further and future experiments should consider testing a wider range of stocking densities. This approach can help farmers with abandoned ponds to restart new and viable production systems rather than resort to construction of new ponds elsewhere.

\section{ACKNOWLEDGMENTS}

We would like to thank Rosiana Sabang, Muhammad Arnold and Ilham (RICA) for assistance during the experiment. Mr Tarunamulia (UNSW and RICA) provided the cartographic work. This research was funded by the Australian Centre for Agricultural Research (ACIAR) and the Government of Indonesia.

\section{REFERENCES}

Ahern, C.R., McElnea, A., \& Baker, D.E. 1998a. Peroxide oxidation combined acidity and sulfate. In C.R. Ahern, Blunden, B., \& Stone, Y. (eds.), Acid Sulfate Soils Laboratory Methods Guidelines. Acid Sulfate Soil Management Advisory Committee, Wollongbar, NSW, p. 4.1-4.17.

Ahern, C.R., McElnea, A., \& Baker, D.E. 1998b. Total oxidisable sulfur. In C.R. Ahern, Blunden, B. \& Stone, Y. (eds.), Acid Sulfate Soils Laboratory Methods Guidelines. Acid Sulfate Soil Management Advisory Committee, Wollongbar, NSW, p. 5.1-5.7.

Ahern, C.R. \& Blunden, B. 1998. Designing a soil sampling and analysis program. In C.R. Ahern, Blunden, B., \& Stone, Y. (eds.), Acid Sulfate Soils Laboratory Methods Guidelines. Acid Sulfate Soil Management Advisory Committee, Wollongbar, NSW, p. 2.12.6.

Ahern, C.R. \& Rayment, G.E. 1998. Codes for acid sulfate soils analytical methods. In C.R. Ahern, Blunden, B., \& Stone, Y. (eds.), Acid Sulfate Soils Laboratory Methods Guidelines. Acid Sulfate Soil Management Advisory Committee, Wollongbar, NSW, p. 3.13.5.

Ahern, C.R. \& McElnea, A. 2004. Calculated sulfur parameters. In Acid Sulfate Soils Laboratory Methods Guidelines. Queensland Department of Natural Resources, Mines and Energy, Indooroopilly, Queensland, Australia, p. B1 1-1-B11-2.

Ahmad, T. 1991. Pengelolaan Peubah Mutu Air yang Penting dalam Tambak Udang Intensif. INFIS Manual Seri No. 25. Direktorat Jenderal Perikanan bekerja sama dengan International Development Research Centre. Direktorat Jenderal Perikanan, Jakarta, 40 pp.

Anonim. 2003. Masterplan pengembangan budidaya air payau di Indonesia. Direktorat Jenderal Perikanan Budidaya. Jakarta, 397 hlm.

Anonim. 2004. Statistik Perikanan Budidaya Indonesia. Direktorat Jenderal Perikanan, Jakarta, $124 \mathrm{hlm}$.

APHA (American Public Health Association). 2005. Standard Methods for Examination of Water and Wastewater. APHA-AWWA-WEF, Washington, D.C., 1,185 pp.

ASEAN (Association of Southeast Asian Nations). 1978. Manual on Pond Culture of Penaeid Shrimp. ASEAN National Coordinating Agency of the Philippines, Manila, $132 \mathrm{pp}$.

Boyd, C.E. 1995. Bottom Soils, Sediment and Pond Aquaculture. Chapman and Hall, New York, $348 \mathrm{pp}$. 
Chiang, P.D.-M., Kuo, C.-M., \& Liu, C.-F. 1989. Pond preparation for shrimp growout. In Akiyama, D.M. (ed.), Proceedings of the Southeast Asia Shrimp Farm Management Workshop. American Soybean Association, Singapore, p. 48-55.

Cholik, F. \& Mustafa, A. 1987. Keragaman berat udang windu hasil budidaya di tambak di Kabupaten Maros dan Pangkep, Sulawesi Selatan. J. Pen. Budidaya Pantai, 3(1): 2227.

Coakes, S.J., Steed, L., \& Price, J. 2008. SPSS: Analysis without Anguish: Version 15.0 for Windows. John Wiley \& Sons Australia, Ltd., Milton, Qld., $270 \mathrm{pp}$.

Durand, S.V. \& Lightner, D.V. 2002. Quantitative real time PCR for the measurement of white spot syndrome virus in shrimp. J. of Fish Diseases, 25: 381-389.

Gosavi, K., Sammut, J., Gifford, S., \& Jankowski, J. 2004. Macroalgal biomonitors of trace metal contamination in acid sulfate soil aquaculture ponds. Science of the Total Environment, 324(1-3): 25-39.

Kirpichnikov, V.S. 1981. Genetic Bases of Fish Selection. Springer Verlag, New York, 410 pp.

Liaw, W.K. 1969. Chemical and biological studies of fishponds and reservoirs in Taiwan. Rep. Fish Culture Res., Fish. Series, Chin. Am. Joint Commission on Rural Reconstruction, 7: 1-43.

Liu, C.-I. 1989. Shrimp disease, prevention and treatment. In Akiyama, D.M. (ed.), Proceedings of the Southeast Asia Shrimp Farm Management Workshop. American Soybean Association, Singapore, p. 64-74.

Mangampa, M., Mustafa, A., dan Mangawe, A.G. 1990. Penelitian pendahuluan pada budidaya tambak sistem semi-intensif dengan menggunakan benur windu, Penaeus monodon yang dibantut. J. Pen. Budidaya Pantai, 6(1): 40-46.

Mangampa, M. \& Mustafa, A. 1992. Budidaya udang windu, Penaeus monodon pada padat penebaran berbeda dengan menggunakan benih yang dibantut. J. Pen. Budidaya Pantai, 8(4): 37-48.

Mangampa, M., Kabangnga, N., Mustafa, A., \& Tjaronge, M. 1994. Budidaya udang windu, Penaeus monodon secara intensif menggunakan benur yang dibantut dalam wadah yang berbeda. J. Pen. Budidaya Pantai, 10(5): 89-95.
Martosudarmo, B. 1983. Effects of Different Substrates and Selected Feeds on the Growth and Survival of Hatchery-Produced Penaeus monodon Postlarvae. Master of Science Thesis. University of the Philippines System, lloilo, $83 \mathrm{pp}$.

Menon, R.G. 1973. Soil and Water Analysis: A Laboratory Manual for the Analysis of Soil and Water. Proyek Survey O.K.T. Sumatera Selatan, Palembang, 190 pp.

Muliani \& Mustafa, A. 1995. Pendederan udang windu, Penaeus monodon dalam tambak tanah gambut menggunakan jenis pelindung berbeda. J. Pen. Perik. Indonesia, I(3): 55-66.

Mustafa, A. \& Mangampa, M. 1990. Usaha budidaya udang tambak menggunakan benur windu, Penaeus monodon yang berbeda lama pembantutannya. J. Pen. Budidaya Pantai, 6(2): 35-48.

Mustafa, A. \& Mansur, H. 1994. Pemanfaatan tambak tanah gambut bukaan baru untuk pendederan benur windu. Warta Balitdita, 6(3): 49-52.

Mustafa, A., Hanafi, A., \& Pantjara, B. 1995. Konstruksi pematang tambak tanah gambut untuk pendederan benih udang windu (Penaeus monodon) dan nener ikan bandeng (Chanos chanos). J. Pen. Perik. Indonesia, I(2): 48-64.

Mustafa, A. 1996. Pendederan Udang Windu (Penaeus monodon Fabricius) di Tanah Gambut Melalui Pengapuran Dasar dan Susulan dengan Dosis Berbeda. Tesis Magister. Program Pascasarjana, Universitas Hasanuddin, Ujung Pandang, $182 \mathrm{hlm}$.

Mustafa, A. 2007. Developing Acid Sulfate Soils for Brackish Water Aquaculture Ponds in South Sulawesi, Indonesia. Doctor of Philosophy Thesis. The University of New South Wales, Sydney, 418 pp.

Parker, N.C. 1987. Feed Conversion Indices: Controversy or Convention. The Progressive Fish-Culturist, 49(3): 161-166.

Poernomo, A. 1988. Pembuatan Tambak Udang di Indonesia. Seri Pengembangan No. 7. Balai Penelitian Perikanan Budidaya Pantai, Maros, $30 \mathrm{hlm}$.

Poernomo, A. 1989. Faktor lingkungan dominan pada budidaya udang intensif. Dalam Bittner, A. (ed.), Budidaya Air. Yayasan Obor Indonesia, Jakarta, hlm. 66-120.

Ponnamperuma, F.N. 1972. The chemistry of submerged soils. Advance Agronomy, 24: 29-96. 
Primavera, J.H. 1977. Survival rate of different postlarvae stages of Penaeus monodon. SEAFDEC Aquaculture Department, Iloilo, Philippines, Quarterly Research Report, 2: 30-33.

Rodriguez, E.M., Bombeo-Tuburan, I., Fukumoto, S., \& Ticar, R.B. 1993. Nursery rearing of Penaeus monodon (Fabricius) using suspended (hapa) net enclosures installed in a pond. Aquaculture, 112: 107-111.

Rohlf, F.J. \& Sokal, R.R. 1981. Statistical Tables. Second edition. W.H. Freeman and Company, New York, 209 pp.

Sammut, J. 1999. Amelioration and management of shrimp ponds in acid sulfate soils: key researchable issues. In Smith, P.T. (ed.), Towards Sustainable Shrimp Culture in Thailand and the Region. ACIAR Proceedings No. 90. Australian Centre for International Agricultural Research, Canberra, p. 102106.

Sammut, J. \& Hanafi, A. 2000. Remediation and Management of Shrimp Ponds Excavated in Acid Sulfate Soils. Report to the World Bank, FAO, NACA and WWF, Bangkok, Thailand, $13 \mathrm{pp}$.

Sammut, J., Mustafa, A., Hanafi, A., Tarunamulia, $\&$ Tahe, S. 2003. Polyculture: extends production life for ponds with acid sulfate soil. Global Aquaculture Advocate June, 6(3): 72 73.
Siddharaju, S., Sultan, K.M.M., \& Menon, V.R. 1980. Nursery rearing of post larvae of two commercially important penaeid prawns in nylon cages. In Silas, E.G. (ed.), Proceedings of the Symposium on Coastal Aquaculture, Part-1: Prawn Culture. Marine Biological Association of India, Cochin, India, p. 403-405.

Smayda, T. 1983. The phytoplankton of estuaries. In Ketchum, B.H. (ed.), Estuaries and Enclosed Seas. Ecosystem of the World 26. Elsevier Scientific Publisher Co., Amsterdam, p. 65-102.

SPSS (Statistical Product and Service Solution). 2006. SPSS 15.0 Brief Guide. SPSS Inc., Chicago, $217 \mathrm{pp}$.

Somalingam, J. \& Murthy, M.N. 1979. Preliminary observation on the nursery management of post larvae of Penaeus monodon. J. of Indian Fisheries Association, 8-9: 6-9.

Yoganandhan, K., Sathish, S., Murugan, V., Narayanan, R.B., \& Hameed, A.S.S. 2003. Screening the organs for early detection of white spot syndrome virus in Penaeus indicus by histopathology and PCR techniques. Aquaculture, 215:21-29.

Yusufzai, S.l. \& Singh, H. 2005. Rearing of Penaeus monodon (Fabricius) postlarvae in floating cages at different stocking densities. Aquaculture Research, 36: 405-408. 